\title{
PÁROSÍTÁSI STRATÉGIÁK POZÍCIÓS JÁTÉKOKON
}

\author{
GYŐRFFY LAJOS
}

\begin{abstract}
Az amőba típusú játékok témaköre a matematika egyik üde színfoltja. A kérdések olykor egy általános iskolás számára is érthetők, egyes válaszokat azonban még ma is kutatnak a kombinatorikusok. Ilyen játékok legismertebb példái a Tic-Tac-Toe és az 5-amőba, melyek mellett azonban számos másik játék is vizsgálatra érdemes. A cikkben bemutatunk néhány nyerő stratégiát sok példával, majd pedig a 9-amőba lehetséges párosításait karakterizáljuk és teljes leírást adunk a párosítások szimmetrikus struktúrájára, melynek során egy négydimenziós kocka is előkerül.
\end{abstract}

\section{Bevezetés}

Gyakran előfordult általános iskolás éveim alatt, hogy egy-egy unalmasabb óra közepén padtársammal előkaptunk egy „kockás” lapot, és valamilyen játékot kezdtünk el játszani, amíg a tanár észre nem vette. Kedvenc játékunk az Amőba, más néven Ötödölő volt. Itt - hasonlóan a normál hipergráf játékokhoz - két játékos felváltva rak saját jeléből ( $\mathrm{X}$ és $\mathrm{O}$ ) egy négyzetrácsos lap négyzeteibe, amíg egyikük meg nem szerez egy teljes nyerőhalmazt. A hipergráf játék szóhasználatot az indokolja, hogy a játék táblája tekinthető egy hipergráfnak, melynek csúcsai a mezők, élei pedig a nyerőhalmazok.

Az ilyen játékokat általában pozíciós játékoknak nevezik, azonban a pozíciós játékok közé minden, pozíciók által jellemezhető játékot besorolhatunk (pl. sakk, malom), így a cikkben a szúkebb és pontosabb hipergráf játék kifejezést használjuk.

Egy hipergráf játék kimenetele háromféle lehet: kezdő nyer, a második nyer vagy pedig döntetlen eredmény születik, amennyiben egyik fél sem jár sikerrel pl. a tábla telítődése előtt. John Nash azonban egy másik játékra már 1949-ben megmutatta, hogy tökéletes játék esetén a második játékos nem nyerhet, hiszen ha lenne nyerő stratégiája, azt a kezdő játékos el tudná lopni, ezt hívjuk stratégialopásnak [7]. Éppen ezért matematikai szempontból indokolható a Maker-Breaker, magyarul Épitö-Romboló játékok bevezetése.

Ezekben a játékokban a kezdő (Maker) célja továbbra is egy nyerőhalmaz teljes megszerzése, a második játékos (Breaker) célja azonban változik a normál, avagy 
Maker-Maker játékhoz képest: Breakerként most akkor nyer, ha meg tudja akadályozni Maker nyerését (Breakernek tehát nem célja nyerőhalmazt szerezni, csak Makert akadályozni). A stratégialopás miatt normál játékokban (tökéletes játék esetén) nem nyerhet a második, a M-B verzióban viszont igen.

Mielőtt továbbmennénk, érdemes néhány szót ejteni a számokról, pl. az egyik legkisebb játék, a Tic-Tac-Toe esetében. A Tic-Tac-Toe játék táblája a $3 \times 3$-as négyzet, nyerőhalmazai pedig a három vízszintes, három függőleges ill. két átlós hármas. Itt összesen 9 ! $\approx 3,6 \cdot 10^{5}$ lehetséges játszma van, $\sum_{i=0}^{9}\left(\begin{array}{c}9 \\ i\end{array}\right)\left(\begin{array}{c}i \\ \lfloor i / 2\rfloor\end{array}\right) \approx 7 \cdot 10^{3}$ lehetséges pozíció és $8^{9} \cdot 6^{9 \cdot 7} \cdot 4^{9 \cdot 7 \cdot 5} \cdot 2^{9 \cdot 7 \cdot 5 \cdot 3} \approx 10^{500}$ lehetséges Breaker stratégia létezik (hiszen Breaker a Maker kezdő 9 lépésére 8, majd a $9 \cdot 7$ lépésre 6, stb. választ tud adni). Ez a szám mutatja, hogy már egy kis játék esetén is nehéz dolgunk van, ha az összes lehetséges stratégiát vizsgáljuk. Tekintsünk néhány példát a hipergráf játékokra.

1.1. Példa. (Tic-Tac-Toe) A két játékos felváltva tesz egy-egy jelet a kilenc négyzetből álló $3 \times 3$-as tábla egy-egy mezőjére. Aki elfoglal egy teljes sort, oszlopot vagy fóátlót, az nyer.

1.2. Példa. (Amőba) A végtelen négyzetrácson (gyakorlatban füzetlapon) játssza két játékos. Felváltva jelölik a mezőket, s aki hamarabb képes öt, egymást követő mezőt vízszintesen, függőlegesen vagy átlós irányban elfoglalni, az nyer.

1.3. Példa. (k-amőba) Az előző játékhoz nagyon hasonló, azonban öt helyett $k$ darab mezőt kell megszerezni a győzelemhez. Jelöljük $\mathcal{H}_{k}$-val a $k$-amőba hipergráfját. A játék az irányok szerint is általánosítható, ha az eredeti négy irány $((0,1),(1,0),(1,1),(-1,1))$ helyett más irányvektorokat veszünk.

1.4. Példa. (Hales-Jewett játékok) A $H J(n, d)$-vel jelölt játék táblája egy $d$ dimenziós kocka, amelyik $n^{d}$ kisebb kockából áll. A nyerőhalmazok pedig a soroknak, oszlopoknak és különféle átlóknak megfelelő $n$-esek. Pl. $H J(3,2)$ a Tic-Tac-Toe.

A 2. fejezetben ismertetjük a legfontosabb lehetséges stratégiákat: a teljes esetvizsgálatot, a súlyfüggvények módszerét, a résztáblákra bontás stratégiáját és a párosításokat, majd áttekintjük, milyen eredményeket adnak ezen módszerek az Amőbára és néhány természetes általánosítására. A 3. fejezetben pedig az egyik legérdekesebb eset, a 9-amőba összes lehetséges jó párosítását keressük meg, jellemezzük és foglaljuk egy szép tulajdonságokkal rendelkező gráfba.

\section{Stratégiák és korábbi eredmények}

\subsection{Lehetséges stratégiák}

A stratégiák közül az elsőként említendő a teljes esetvizsgálat. Láthattuk azon- 
ban a bevezetőben, hogy a legtöbb esetben ez már viszonylag kis játékok esetén is teljesen reménytelennek tünik. Okos megfontolásokkal azonban néha mégis hozhat eredményt. A Tic-Tac-Toe esetében ezzel a módszerrel kapjuk, hogy a MakerMaker (M-M) játék döntetlen, a Maker-Breaker (M-B) játék viszont kezdő nyerő. Ez a tény is mutatja, hogy M-B esetben Makernek könnyebb dolga van nyerni, mint a M-M esetben, hiszen itt sosem kell foglalkoznia a második játékos fenyegetéseivel. A továbbiakban (hacsak külön nem említjük) a M-B játékokkal foglalkozunk.

Egy másik, régóta ismert stratégia a súlyfüggvények stratégiája, mely Erdős Pál és John Selfridge nevéhez füződik [4]. Itt a nyerő halmazokat veszélyességük szerint súlyozzuk, általában kettőhatványokkal.

2.1. TÉTEL. (Erdős-Selfridge) [4] Breaker nyer a $\mathcal{H}=(V, E)$ hipergráf játék $M-B$ változatában, ha Maker kezd és $\sum_{A \in E} 2^{-|A|+1}<1$, ahol $|A|$ jelöli az $A$ nyerőhalmaz elemszámát, az összegzést pedig az összes élre elvégezzük.

Ha egy hipergráf megfelel a tételbeli kezdeti feltételnek, akkor a Breaker nyerő stratégiát egy mohó algoritmus adja. A megfelelően választott súlyfüggvény alapján Breaker mindig azt a mezőt választja, amelyik a legnagyobb csökkenést okozza a súlyok összegében. Mivel a súlyfüggvények összege kezdetben is egynél kisebb és a játék során minden lépésben csökken, így a játék végére sem érheti el az 1-et. Ha viszont volna Makernek nyerő lépése, akkor ezen lépés előtt egy egyelemű nyerőhalmaz lenne, melyre $2^{-|1|+1}=1$ lenne, ami ellentmondás, tehát Maker nem nyerheti meg a játékot. Súlyfüggvények általában sürübb hipergráfokra adnak nyerő stratégiát, ilyenekre találunk példákat a Beck [2] könyvben.

A következő stratégia a résztáblákra bontás [9], melyben Breaker előzetesen felbontja a végtelen négyzetrácsot kisebb résztáblákra, melyeken új nyerőhalmazokat definiál. Breaker egy lépésben mindig azon a táblán lép, amelyiken Maker is lépett az utolsó lépésében. Megfelelő felbontás esetén, ha Breakernek sikerül megakadályoznia, hogy Maker megszerezzen akár csak egy nyerőhalmazt valamelyik résztáblán, akkor a teljes táblán is nyeri a játékot.

Utoljára maradt a minket leginkább érdeklö párosítások stratégiája [7]. Általános menete, hogy Breaker előre bepárosítja a tábla elemeit, és ha Maker választ egy elemet, Breaker lépésében annak a párját választja.

2.1. Definíció. Adott egy $\mathcal{H}=(V, E)$ hipergráf. A $\rho: X \rightarrow Y$ bijekciót, ahol $X, Y \subset V(\mathcal{H})$ és $X \cap Y=\emptyset$ párosításnak nevezzük a $\mathcal{H}$ hipergráfon.

2.2. Definíció. Egy $(x, \rho(x))$ pár blokkol egy $A \in E(\mathcal{H})$ élt, ha $A$ a pár mindkét elemét tartalmazza. Ha a $\rho$ párosítás párjai blokkolják a hipergráf összes élét, azt mondjuk, hogy $\rho$ egy jó párosítás a $\mathcal{H}$ hipergráfon.

A párosítások így egy lehetséges Breaker nyerő stratégiát adhatnak a hipergráf játékokon. A $\rho$ jó párosítás a $\mathcal{H}$ hipergráfon a következőképpen alkalmazható nyerő stratégiaként Breaker számára a Maker által választott $x$ esetén: (a) ha 
$x \notin X \cup Y$, akkor Breaker tetszőleges csúcsot választhat; (b) ha $x \in X$, akkor Breaker $\rho(x)$-et választja; (c) $x \in Y$ esetén $\rho^{-1}(x)$-et választja. Követve a $\rho$-beli párokat a M-B játékban, minden Maker által választott $x \in X \cup Y$ elem után Breaker $\rho(x)$-et, $x$ párját választja, vagy $x \in Y$ esetén fordítva (ha $x \notin X \cup Y$, akkor Breaker tetszőleges csúcsot választhat). Így Breaker blokkolja az összes élt és nyeri a játékot.

\subsection{Eredmények az amöbára}

Nyilvánvaló, hogy a tökéletes stratégiákat tekintve, ha Makernek van nyerő stratégiája egy adott $\mathcal{H}_{k}$ hipergráfon, akkor a $k$-nál kisebb értékekre is nyeri a játékot. Hasonlóan, ha Breaker rendelkezik a $\mathcal{H}_{k}$ hipergráfon nyerő stratégiával, akkor minden $k$-nál nagyobb értékre is nyer.

2.2. TÉTEL. Maker nyeri az 5-amőbát (és így az ötnél kisebbeket is) a végtelen táblán.

A bizonyítás számítógépes esetvizsgálaton alapul, mely 1993-ban Allisnek és társainak [1] sikerült. Jegyezzük meg, kezdő nyerése nem bizonyított még a M-M játékra, kizárólag a $15 \times 15$-ös, ill. a $19 \times 19$-es táblákon. A meglepő tény oka, hogy újabb nyerőhalmazok vétele elronthatja a kezdő nyerési stratégiáját a M-M esetben (ún. extra set paradoxon).

Másik oldalról vizsgálva, az Erdős-Selfridge-tétel egy trükkös alkalmazása szerint (ld. Beck [2]) Breaker nyeri a 13-amőbát. A párosítások már a $k=9$ eset Breaker nyerését is adják, a résztáblákra bontás stratégiájával pedig már a 8-amőba Breaker nyerése is megmutatható.

2.3. TÉTEL. Breaker nyeri a 8-amőbát (és így a nyolcnál nagyobbakat is) a végtelen táblán [2,9].

A bizonyítás A. Brouwer nevéhez füződik, aki 1980-ban T.G.L. Zetters álnéven publikálta az eredményt. Az 1. ábra negyedik része szerint felosztjuk a táblát $3 \times$ 4-es paralelogrammákra, melyeken mind a három vízszintes négyes, mind a négy átlós hármas és a két vonallal jelzett függőleges kettes egy-egy nyerőhalmaz lesz, a harmadik ábra szerint. Ha egy ilyen paralelogrammán Breaker meg tudja akadályozni Makert célja elérésében, akkor az egész táblán is, így Breaker nyer. Az 1. ábra első két része a 9-amőbára mutat egy Breaker nyerő résztáblákra bontást.

2.1. Megjegyzés. A $k=6$ ill. 7 esetek a végtelen (vagy elég nagy, pl $100 \times 100$ ) táblán a mai napig nyitott kérdések.

2.2. Megjegyzés. Párosítással a $k=9$ eset a legkisebb, amelyre Breaker nyerése belátható. Ez A. Hales és R. Jewett nevéhez füződik [7], és a 2. ábrán látható, ahol a párokat a vonallal összekötött négyzetek szemléltetik. A párosítást a végtelen síkon a bekeretezett 8-as négyzet természetes kiterjesztésével kapjuk. 


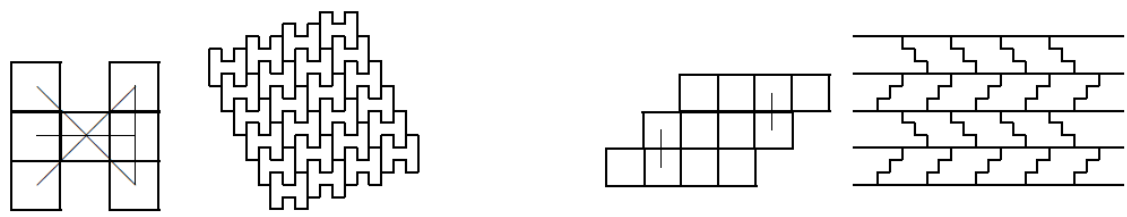

1. ábra. Résztáblákra bontás a 9- és a 8-amőba ellen

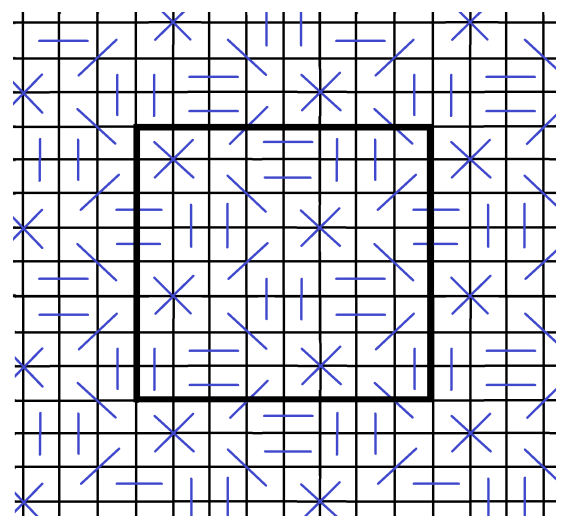

2. ábra. Párosítási stratégia a 9-amőba ellen

A következő állítás megmutatja, hogy nem létezhet jó párosítás a $k$-amőba hipergráfjára, ha $k<9$.

Egy $\mathcal{H}$ hipergráfra legyen $d_{2}\left(\mathcal{H}\right.$ ) (röviden $d_{2}$ ) azon élek maximális száma, amelyeket blokkolhat egy két csúcsból álló pár, vagyis $d_{2}$ a maximális közös fok (co-degree). Ezen értéket szemléletesen nevezhetjük a pár blokkolási erejének is.

2.1. Állítás. [3] Ha létezik egy $\rho$ jó párosítás a $\mathcal{H}=(V, E)$ hipergráfra, akkor $d_{2}|X| / 2 \geq|\mathcal{G}|$ egyenlötlenségnek teljesülnie kell minden $X \subset V$ esetén, ahol $\mathcal{G}=$ $\{A: A \in E, A \subset X\}$.

Bizonyítás. Az $X$ részhalmazra mint résztáblára fogunk utalni. $\mathcal{G}$ éleit csak $X$-beli párokkal blokkolhatjuk. Legfeljebb $|X| / 2$ ilyen pár van $\rho$-ban az $|X|$ méretü résztáblán. Mivel egy pár legfeljebb $d_{2}$ élt blokkol, $|X| / 2$ pár legfeljebb $d_{2}|X| / 2$ élt blokkolhat. Így, ha ennél több él van a résztáblán, nem létezhet jó párosítás.

A 2.1. Állítás segítségével megkapjuk, hogy nincs jó párosítás $\mathcal{H}_{k}$-ra, ha $k<9$. A $\mathcal{H}_{k}$ hipergráfban $d_{2}=k-1$, vagyis egy pár legfeljebb $k-1$ élt blokkolhat. Ennyit is csak abban az esetben, ha a pár dominó, azaz szomszédos elemekből álló 
pár. Ha $X$ egy $n \times n$ résztábla egy elég nagy $n$-re, akkor $|\mathcal{G}|=4 n^{2}+O(n)$ mivel minden négyzetből négy él kezdődik (egy vízszintes, egy függőleges és két átlós, kivéve a határokat). A 2.1. Állításból kapjuk, hogy $(k-1) n^{2} / 2 \geq 4 n^{2}+O(n)$; vagyis $k \geq 9+O(1 / n)$.

Amennyiben az irányok közül eltekintünk néhánytól, kisebb, ám szintén érdekes problémákat kaphatunk:

2.2. Állítás. Ha az egyik átlót elhagyjuk és csak a három megmaradó $(0,1)$, (1,0), (1,1) irányt vesszük, akkor a kapott tábla ekvivalens a hatszögráccsal. Ezen a táblán Maker nyeri a 4- vagy annál kisebb eseteket, Breaker pedig párosítással nyeri a 7- vagy annál nagyobb eseteket, ld. 3. ábra.

2.3. Megjegyzés. A $k=5$ ill. 6 esetek még nyitott kérdések.
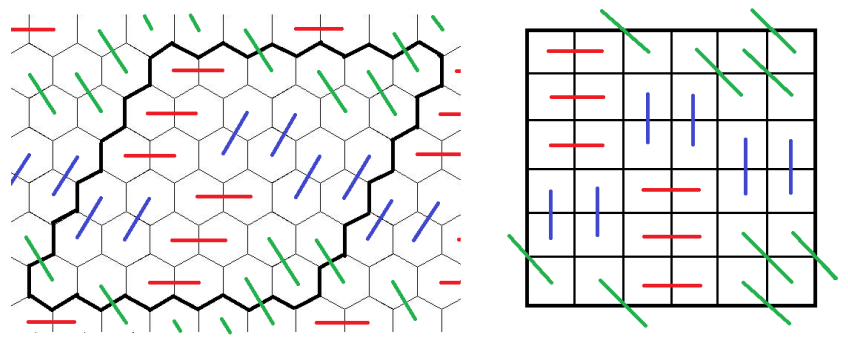

3. ábra. Párosítás a 3-irányú 7-amőba $\left(h_{7}\right)$ ellen

2.3. Állítás. Ha csak az (1,0) és (0,1) irányokat vesszük, Maker szintén 4-ig nyer, 5-től azonban itt már Breaker nyer, szintén párosításokkal, ld. 4. ábra.
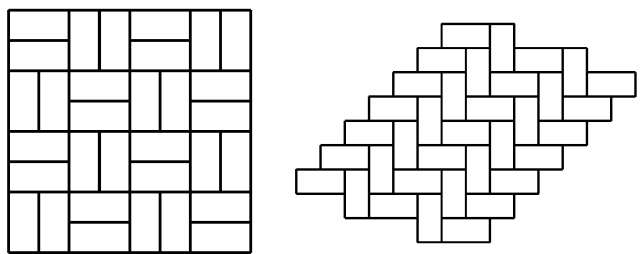

4. ábra. Párosítás a kétirányú 5-amőba $\left(P_{5}\right)$ ellen

Ha csak egy irányt veszünk, ott 2 és 3 között van a Maker és Breaker nyerése közti váltás. Érdekesség, hogy a kétirányú 5-amőba elleni védekezésre csak a 4. ábrán látható párosítások létezhetnek [3], melyek mindegyike gyakori térkövezési minta pl. Szegeden is, ld. 5.ábra. Az eredményeket az 1.táblázatban foglaltuk össze, ahol $k$ a nyerőhalmazok hossza, $n$ pedig az irányok száma. 


\begin{tabular}{|c||c|c|c|c|c|c|c|c|}
\hline$n \backslash k$ & 2 & 3 & 4 & 5 & 6 & 7 & 8 & $\geq 9$ \\
\hline \hline 1 & $\mathrm{M}$ & $\mathrm{B}$ & $\mathrm{B}$ & $\mathrm{B}$ & $\mathrm{B}$ & $\mathrm{B}$ & $\mathrm{B}$ & $\mathrm{B}$ \\
\hline 2 & $\mathrm{M}$ & $\mathrm{M}$ & $\mathrm{M}$ & $\mathrm{B}$ & $\mathrm{B}$ & $\mathrm{B}$ & $\mathrm{B}$ & $\mathrm{B}$ \\
\hline 3 & $\mathrm{M}$ & $\mathrm{M}$ & $\mathrm{M}$ & $?$ & $?$ & $\mathrm{~B}$ & $\mathrm{~B}$ & $\mathrm{~B}$ \\
\hline 4 & $\mathrm{M}$ & $\mathrm{M}$ & $\mathrm{M}$ & $\mathrm{M}$ & $?$ & $?$ & $\mathrm{~B}$ & $\mathrm{~B}$ \\
\hline
\end{tabular}

1. táblázat. Ki nyeri az $n$ irányú $k$-amőbát
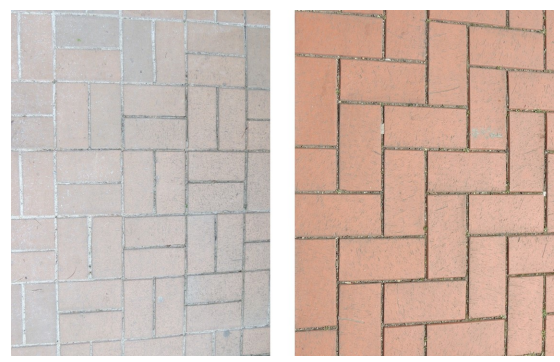

5. ábra. $P_{5}$ párosításai a Dugonics téren

Általában is igaz a $d$-dimenziós végtelen táblán, hogy ha $n$ irányban engedjük meg az egyforma hosszú nyerőhalmazokat, akkor $k<2 n+1$ esetekben nem létezhet párosítás a megfelelő $k$-amőbákra, ez adódik a 2.1. Állításból. Fordítva viszont egyelőre nem bizonyított, bár sejtjük, hogy $k=2 n+1$ esetben mindig létezik is párosítás [8]. Erre egy példát mutatunk 3 dimenzióban, a 6. ábrán.
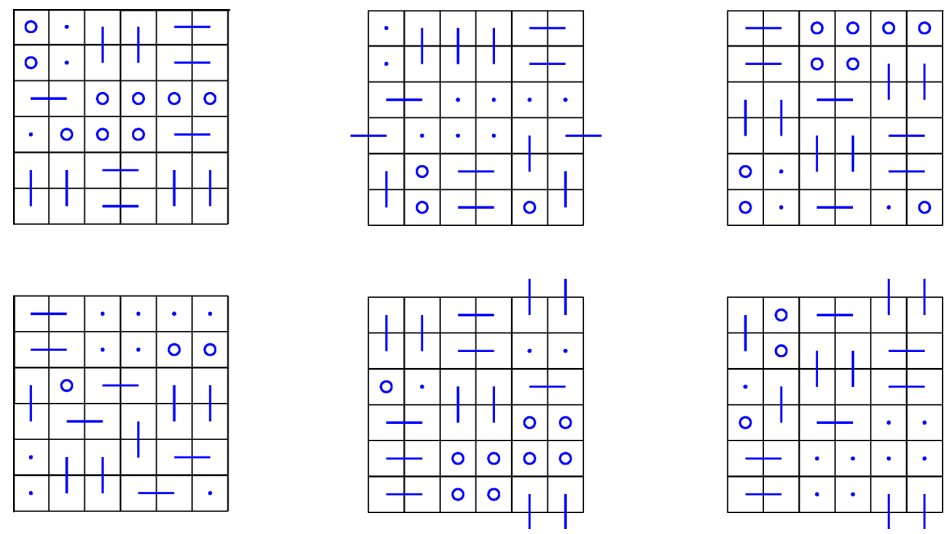

6. ábra. A 3D 7-amőba egy lehetséges Breaker nyerő párosítása 
2.4. Állítás. [5] Létezik jó (azaz Breaker nyerő) párosítás a 3 dimenziós, három irányú $((1,0,0),(0,1,0),(0,0,1))$ 7-amőbára, ld. 6. ábra (ahol a pontok és karikák jelölik a függőleges párokat, a hat négyzet pedig, a bal felsőtől kezdve a jobb alsóig, a párosítás rétegeit adja).

A legélesebb esetben, vagyis amikor $k=2 n+1$, a párosításbeli párokat valamilyen értelemben optimálisan kell használnunk, hiszen ha egy pár nem blokkolja a lehető legtöbb élt, vagy egy él blokkolására több párt is elhasználunk, akkor már nem állhat egyenlőség a 2.1. Állításban. Mielőtt a következő részben rátérnénk a két dimenzióban érdekes eset, a 9-amőba párosításainak vizsgálatára, nézzük meg a hipergráf játékoknak a Beck József által megadott [2] osztályozását.

0. Triviális nyerés: Ebbe a kevéssé érdekes osztályba azon hipergráfok tartoznak, amelyekben minden játszma kezdő nyerő. Ha $n$ a legkisebb méretü él, $|V| \geq 2 n-1$ és $V$ minden $n$-elemü halmaza él (pl. $2 \times 2$-es Tic-Tac-Toe).

1. Kényszerített győzelem: Ebben az osztályban minden játszmának van győztese, vagyis nem létezik döntetlen. Így az osztályban minden játék kezdő nyerő, hiszen mivel döntetlen nincs, a stratégialopás adja az eredményt. A nyerő stratégia mikéntje azonban nem feltétlenül ismert (pl. $3 \times 3 \times 3$-es Tic-Tac-Toe).

2. Finom győzelem: Ide tartoznak azok a játékok, melyekben létezik döntetlen pozíció, ennek ellenére a kezdő játékosnak létezik nyerő stratégiája a normál játékban (pl. 3- és 4- és 5-amőba a 19 × 19-es táblán).

3. Finom döntetlen: Azon hipergráfok osztálya, melyek normál verziója döntetlen, de a Maker-Breaker játékot nyeri Maker (pl. Tic-Tac-Toe).

4. Erös döntetlen: Létezik Breaker nyerő stratégia a M-B játékban, de párosítási stratégia nem (pl. 8-amőba, sejtjük, hogy a 6- és 7-amőba is).

5. Párosításos döntetlen: Ezen osztály elemeire létezik Breaker nyerő párosítási stratégia (pl. 9-amőba).

\section{A 9-amőba párosításai}

A korábban említett optimalitás azt jelenti a 9-amőba $\left(\mathcal{H}_{9}\right)$ esetén, hogy:

(a) egy párosításban szereplő párok mindegyike pontosan $k-1$ élt blokkol (vagyis szomszédos elemekből) áll minden pár, ezt dominó párosításnak nevezzük);

(b) minden élt pontosan egy pár blokkol (ebből az egy egyenesen elhelyezkedő párok 8-periodicitása következik);

(c) minden mező le van fedve egy párral. 
Egy olyan mezőt, ahol a fenti három feltétel egyike sérül, anomáliának fogunk nevezni. A 2.1. Állítás $O(n)$ tagja miatt ilyen előfordulhatna a táblán, azonban [5] cikkben sikerült bebizonyítani, hogy mégsem lehetséges.

3.1. Definíció. A végtelen négyzetrácsos sík egy párosítása $k$-tóruszos, ha az éppen egy $k \times k$-as tórusz kiterjesztése a végtelen síkra, ahol $k$ minimális.

3.1. Megjegyzés. A 2. ábrán látható Hales-Jewett párosítás pl. 8-tóruszos, hiszen a párosítás a bekeretezett $8 \times 8$-as négyzet ismétlődése a végtelen síkon.

3.1. TÉTEL. [5] Tegyük fel, hogy létezik egy jó párosítás $\mathcal{H}_{9}$-re. Akkor az csak 8- vagy 16-tóruszos lehet. Ilyen párosítások vannak is, ld. 7. és 8. ábra.
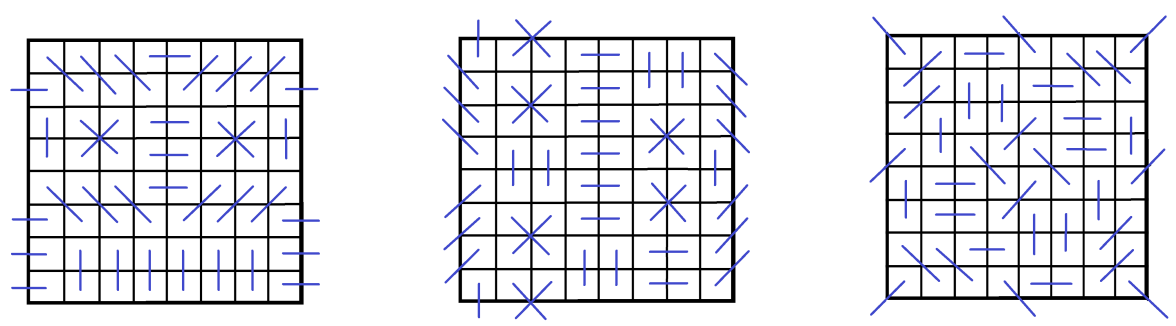

7. ábra. Három különböző, 8-tóruszos jó párosítás $\mathcal{H}_{9}$-re

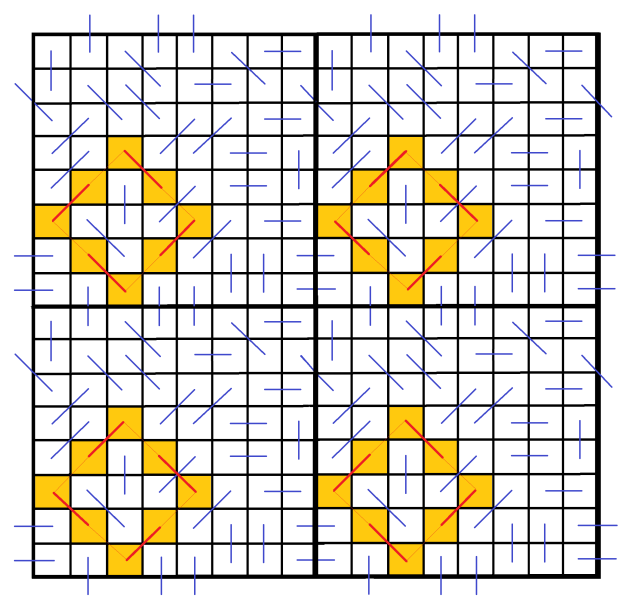

8. ábra. Egy 16-tóruszos jó párosítás $\mathcal{H}_{9}$-re 
3.2. TÉTEL. [5] Egy 8-tóruszos jó párosításból akkor és csak akkor származtatható 16-tóruszos jó párosítás, ha létezik egy másik, különböző 8-tóruszos jó párosítás, mely csak néhány átlós dominóban különbözik az elsőtől úgy, hogy az uniójuk egy átlós alternáló körrendszert ad. Összesen két ilyen lehetséges alternáló körrendszer fordulhat elö, melyek a 9. ábra bal oldalán és közepén láthatók, világossal jelölve az alternatív párok.
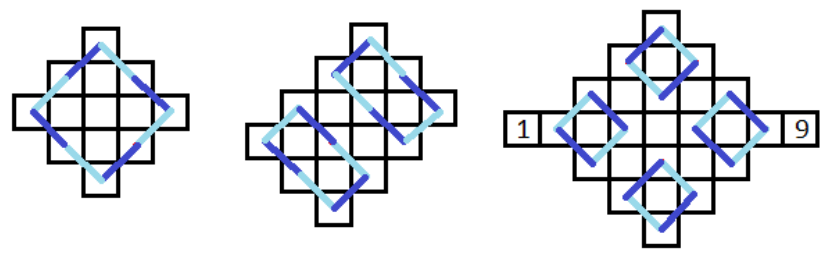

9. ábra. Lehetséges alternáló körrendszerek

Mivel minden 16-tóruszos jó párosítás két átlós körökben eltérő 8-tóruszosból származik, a továbbiakban csak a 8-tóruszos párosításokkal foglalkozunk. Egy 8-tóruszos párosítás jó párosítás a 8-tórusz játékra is, ahol a játék táblája a 8-tórusz, élei pedig a 8 hosszú halmazok vízszintesen, függőlegesen és átlósan. Fordítva nem feltétlenül igaz, hiszen a 8-tórusz játék jó párosításai között lehetnek nem dominókat tartalmazók is. Ha azonban csak dominókat tartalmazó párosításokat veszünk, a kapcsolat kétirányú.

Programmal megvizsgáltuk [6], hány különböző jó párosítás létezik. A válasz egy elég nagy prímszám lett: 194543. A keresés során nem csak a párosítások megtalálása okozott nehézségeket, hanem a kapott objektumok megkülönböztetése is. Olykor két nagyon különbözőnek tünő párosításról is kiderülhet, hogy izomorfak, ld. 10. ábra, ahol a jobb oldali ábrán vékony vonalakkal kiemeltünk négy darab háromszöget, melyek a bal oldali ábrán is beazonosíthatók.
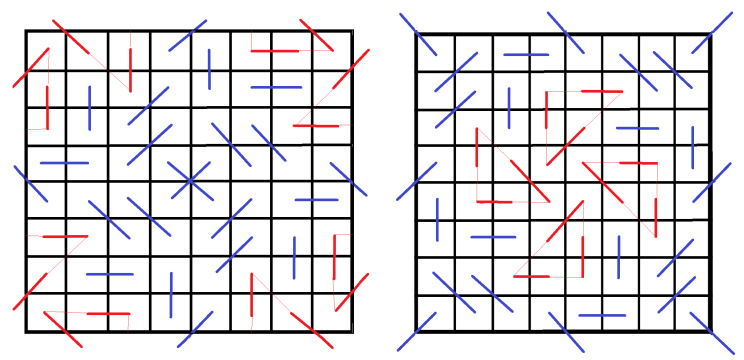

10. ábra. Két eltérőnek tünő, de izomorf párosítás 
A párosítások között egy természetes kapcsolat definiálható: ha egy párt irányban eltolunk egy mezővel, akkor persze keletkezik egy üres mező ill. egy olyan, amibe két pár is belelóg (ami lehetetlen egy jó párosításban). Azonban, ha a dupla mezőről továbbtoljuk a másik párt, és ezt addig ismételjük, amíg körbeér (mivel 64 mezőnk van csak, biztosan körbe fog), akkor egy másik jó párosítást kapunk, pl. 11. ábra. Így a kapcsolat segítségével egy gráfot is definiálhatunk, melynek csúcsai azösszesen 194543 darab párosítás, melyeket akkor kötünk össze, ha létezik köztük eltolás kapcsolat.
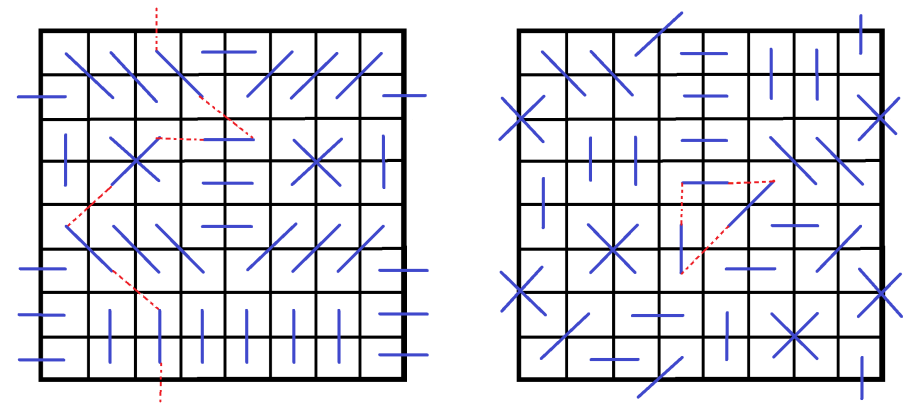

11. ábra. Két példa az eredeti párosításokból kapható, eltolt piros (szaggatott) éleket is tartalmazó új párosításokra

Az így kapott gráf majdnem összefüggő, 194333 csúcsa ugyanabban az összefüggő komponensben található. Azonban akad néhány kisebb komponens is, melyek között a 4-dimenziós kocka hálója is felbukkan, ld. a 12. ábra közepén. A gráf háromszögmentes és összes feszített köre négy hosszú. 14 komponensből áll, fokszámai 1 és 11 között változnak, az átlagfokszám 5,47.
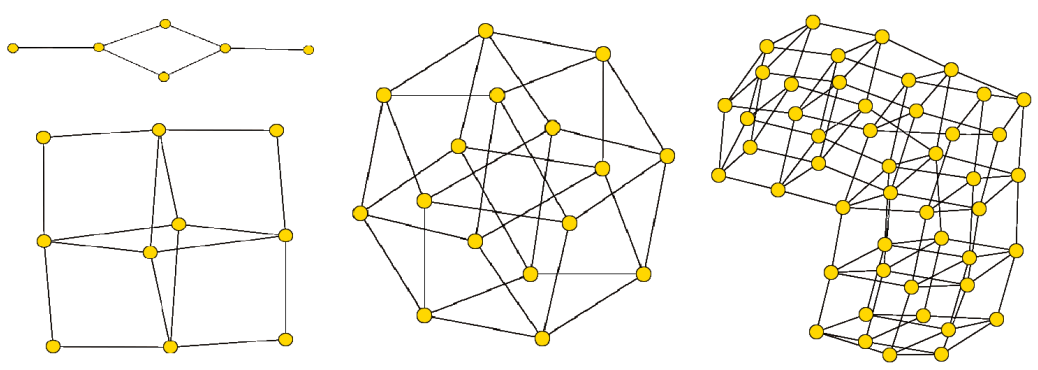

12. ábra. Néhány kisebb komponense a gráfnak

Hasonlóan a hatszögrácson is megszámolhatjuk a párosításokat ill. felépíthetjük a gráfot. Ekkor azt kapjuk, hogy 26 különböző jó párosítás van, melyek egy összefüggő gráfot adnak. 


\section{4. összefoglalás}

A cikkben hipergráf játékokkal foglalkoztunk. Ismertettük a lehetséges nyerő stratégiákat, majd áttekintettük az Amőba különböző változataira adott eredményeket. Megemlítettük, hogy a hagyományos, 4-irányú $k$-amőba Maker-Breaker játékban a $k=6$ és $k=7$ esetek a mai napig nyitott kérdések. Hasonlóan nyitottak a 3 -irányú $k$-amőba $k=5$ és $k=6$ esetei. A cikk további részében a 9 -amőba lehetséges párosításaival foglalkoztunk, melyek mindegyike 8- illetve 16-tóruszos szimmetriákkal rendelkezik. Utóbbiakból mindegyik két különböző 8-tóruszos párosításból kapható, előbbiekből pedig programmal 194543 darab különbözőt kaptunk. A párosítások között egy kézenfekvő kapcsolatot találva gráfba rendeztük mind a 194543 párosítást, mely gráf tulajdonságait szintén leírtuk.

\section{Köszönetnyilvánítás}

Jelen kutatást a Nemzeti Kutatási, Fejlesztési és Innovációs Hivatal az SNN117879 sz. pályázatával támogatta, valamint az EFOP-3.6.1-16-2016-00008 azonosítójú, EU társfinanszírozású projekt részben támogatta.

\section{Hivatkozások}

[1] L.V. Allis, H.J. VAn Den Herik And M. P. Huntjens: Go-Moku solved by new search techniques, Proc. 1993 AAAI Fall Symp. on Games: Planning and Learning, AAAI Press Tech. Report FS93-02, pp. 1-9 (1993). DOI: 10.1111/j.1467-8640.1996.tb00250.x

[2] J. Beck: Combinatorial Games, Tic-Tac-Toe Theory, Cambridge University Press (2008). DOI: $10.1017 / \mathrm{CBO} 9780511735202$

[3] A. Csernenszky, R. Martin and A. Pluhár: On the Complexity of Chooser-Picker positional games, Integers, Vol. 12, pp. 427-444 (2011). DOI: 10.1515/integ.2011.113

[4] P. ERdős AND J.L. SElfRIDGE: On a combinatorial problem which is complete in polynomial space. Journal of Combinatorial Theory Series A, Vol. 14, pp. 298-301 (1973). DOI: 10.1016/0097-3165(73)90005-8

[5] L. Győrffy, G. Makay and A. Pluhár: Pairing strategies for the 9-in-a-row game, Ars Mathematica Contemporanea, Vol. 16, pp. 97-109 (2019).

DOI: $10.26493 / 1855-3974.1350 .990$

[6] L. Györffy, G. MAKAy AND A. London: The structure of pairing strategies for $k$-ina-row type games, Acta Cybernetica, Vol. 23, pp. 561-572 (2017). DOI: 10.14232/actacyb.23.2.2017.8

[7] A.W. Hales And R.I. Jewett: Regularity and positional games, Transactions of the American Mathematical Society, Vol. 106, pp. 222-229 (1963). DOI: 10.1090/S0002-9947-19630143712-1 
[8] K. Kruczek and E. Sundberg: A pairing strategy for Tic-Tac-Toe on the integer lattice with numerous directions, Electronic J. Combinatorics, Vol. 15 No. 1 (2008). DOI: $10.37236 / 917$

[9] Pluhár András: Pozíciós játékok, Szigma, Vol. 3-4, pp. 111-130 (2007).

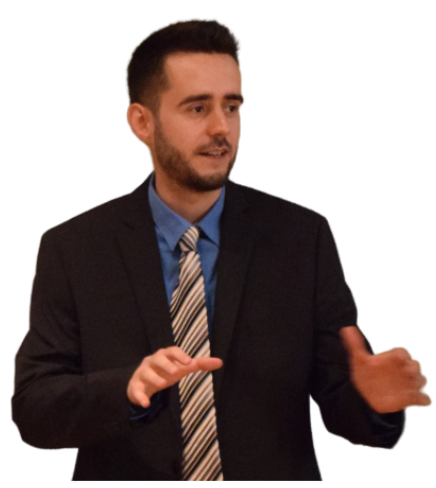

Dr. Győrffy Lajos

SZTE Bolyai Intézet,

6720 Szeged, Aradi vértanúk tere 1.

lgyorffy@math.u-szeged.hu
Győrffy Lajos 1989-ben született Bonyhádon, ahol középiskolai tanulmányait is végezte Katz Sándor irányításával. Mesterszakos diplomáját 2013-ban szerezte a Szegedi Tudományegyetem Alkalmazott Matematikus szakán, majd 2019-ben PhD fokozatot szerzett matematikusként, Pluhár András vezetésével. 2018-ban a Szegedi Akadémiai Bizottság fiatal kutatóknak szánt pályázatán I. helyezést ért el. Jelenleg a Bolyai Intézet kutatója, ahol kombinatorikus játékok témában kutat. Öt nemzetközi folyóiratban megjelent publikációja van.

\section{PAIRING STRATEGIES ON POSITIONAL GAMES}

\section{LAJOS GYŐRFFY}

Positional games are one of the most beautiful topics in mathematics. However, while some questions are interesting for a primary school student, certain answers are hidden even for the best mathematicians. The most well-known games are the Tic-Tac-Toe and the 5-in-a-row, although there are some other worthwhile examples. In this paper we show some winning strategies, then we characterize all pairing strategies of the 9-in-a-row game and give a full description to the highly symmetric structure of those pairings, in which we will meet the three-dimensional cube, as well.

Keywords: Pairing Strategies, Positional Games, k-in-a-row

Mathematics Subject Classification (2000): 05C65, 05C15 